\title{
小叶栋分布格局对末次盛冰期以来气候变化的响应
}

\author{
李圭 张兴旺 方炎明*
}

南京林业大学南方现代林业协同创新中心, 南京 210037; 南京林业大学生物与环境学院, 南京 210037

摘 要 小叶柇(Quercus chenii)是华东植物区系的代表树种, 具有很高的生态、经济价值。为重建冰期以来小叶柇地理分布 格局的变迁历史、了解环境因子对潜在地理分布的制约机制, 为小叶栎种质资源保护和管理提供科学依据, 该研究基于 55 条 分布记录和 8 个环境变量, 利用MaxEnt模型模拟小叶柇在末次盛冰期、全新世中期、现代和 2070 年(温室气体排放情景为典型 浓度目标8.5)的潜在分布区, 利用多元环境相似度面和最不相似变量分析探讨气候变迁过程中环境异常区域和引起潜在地理 分布改变的关键因素, 综合应用贡献率及置换重要值比较、Jackknife检验评估制约现代地理分布的主要因子, 采用响应曲线 确定环境变量的适宜区间。研究结果表明: MaxEnt模型的预测准确度极高, 受试者工作特征曲线下的面积(AUC值)达0.986 $9 \pm$ 0.004 5; 现代高度适宜区在安徽南部、浙江西部、江西东北部和湖北东部; 影响小叶係地理分布的主要气候因子为气温和降 水量, 气温更重要; 最干季平均气温可能是制约小叶柇向北分布的关键因素; 未次盛冰期时, 小叶柇高度适宜区位于东海大 陆架内; 全新世中期适宜分布区轮廓已与现代近似; 2070年适宜分布区向北移，高度适宜区面积增大，与末次盛冰期、全新世 中期和现代相比, 这一时期的气候异常程度最高。气温季节变化和降水季节变化可能是引起地理分布变迁的重要气候因素。 关键词 小叶标; MaxEnt模型; 末次盛冰期; 气候变化; 分布格局

引用格式: 李圭, 张兴旺, 方炎明 (2016). 小叶栋分布格局对末次盛冰期以来气候变化的响应. 植物生态学报, 40, 1164-1178. doi: 10.17521/cjpe.2016.0032

\section{Responses of the distribution pattern of Quercus chenii to climate change following the Last Glacial Maximum}

LI Yao, ZHANG Xing-Wang, and FANG Yan-Ming*

Co-Innovation Center for the Sustainable Forestry in Southern China, Nanjing Forestry University, Nanjing 210037, China; and College of Biology and the Environment, Nanjing Forestry University, Nanjing 210037, China

\section{Abstract}

Aims Quercus chenii is a representative species of the flora in East China, with high ecological and economic values. Here, we aim to simulate the changes in the distribution pattern of this tree species following the Last Glacial Maximum (LGM) and to explore how climatic factors constrain the potential distribution, so as to provide scientific basis for protection and management of the germplasm resources in Q. chenii.

Methods Based on 55 presence point records and data on eight environmental variables, we simulated the potential distribution of Q. chenii during the Last Glacial Maximum, mid-Holocene, present and the year 2070 (the scenario of greenhouse gas emission is Representative Concentration Pathway 8.5) with MaxEnt model. The novel climate area and main factors influencing the changes in distribution pattern were evaluated by multivariate environmental similarity surface analysis and the most dissimilar variable analysis. The importance of environmental variables was evaluated by percent contribution, permutation importance and Jackknife test. Response curves were used to estimate the suitable value range of each variable.

Important findings The accuracy of MaxEnt model is very high, as indicated by the value of the area under the receiver operator characteristic curve of $0.9869 \pm 0.0045$. The highly suitable region for the present distribution covers southern Anhui, western Zhejiang, northeastern Jiangxi and eastern Hubei. The main factors affecting the potential distribution of $Q$. chenii are temperature and precipitation, with the former being more important. Mean temperature of the driest quarter is likely the main factor restricting Q. chenii growing in the north. During the LGM, the East China Sea Shelf occurs as the highly suitable region for the distribution of Q. chenii. In the mid-Holocene, the outline of the suitable area for the distribution of Q. chenii is similar to the present. The potential distribution region will likely move northward and experience an area expansion under the climate condition

收稿日期Received: 2016-01-17 接受日期Accepted: 2016-05-09

* 通信作者Author for correspondence (E-mail: jwu4@njfu.edu.cn) 
in 2070. At that time, climate anomaly will also be most severe compared to the LGM, mid-Holocene and present. Temperature seasonality and precipitation seasonality may be the main climatic factors promoting changes in the distribution pattern of $Q$. chenii.

Key words Quercus chenii; MaxEnt model; Last Glacial Maximum; climate change; distribution pattern

Citation: Li Y, Zhang XW, Fang YM (2016). Responses of the distribution pattern of Quercus chenii to climate change following the Last Glacial Maximum. Chinese Journal of Plant Ecology, 40, 1164-1178. doi: 10.17521/cjpe.2016.0032

末次盛冰期以来地球气候系统的剧烈变化改变 了全球大部分地区的植被、冰盖体积和海洋表面状 况(中国第四纪孢粉数据库小组, 2000), 冰期和间冰 期的反复交替对现代生物区系的地理分布格局和遗 传结构产生了巨大的影响(Hewitt, 2004)。在末次盛 冰期(21 ka BP)全球大降温背景下, 草原大面积向 南扩张, 抵达现在的中亚热带北界, 华南热带地区 热带植被消失, 演变为亚热带常绿阔叶林(中国第 四纪狍粉数据库小组, 2000; 刘金陵和王伟铭, 2004)。中全新世(6 ka BP) 是距今最近的一个暖期, 当时我国东部森林生态系统向北推进, 温带落叶阔 叶林向北推进约 4 个纬度(中国第四纪孢粉数据库小 组, 2000)。而在未来全球气候持续变暖的情境下, 中国气温升幅在1.6-5.0 ${ }^{\circ} \mathrm{C}$, 年降水量将增加 $1.5 \%-$ 20\% (江志红等, 2008)。对某些物种而言, 适宜分布 范围可能逐渐减小, 气候变化也成为威胁生物多样 性的新因素, 已有证据支持某些物种的灭绝即由此 导致(Bellard et al., 2012)。因此, 研究植物分布格局 对气候变化的响应对于揭示物种形成、迁移和扩散 历史, 提出合理有效的生物多样性保护措施有着重 要的理论与实践意义。

MaxEnt模型被广泛地应用于气候变化条件下 物种潜在分布区的预测。它基于现代分布记录和环 境数据构建物种分布模型, 并可以推广到诸如气候 变化等新的情境, 其假设训练数据代表了现有分布 区的环境状况, 并且在这种情境下物种处于平衡状 态(Elith et al., 2010)。该模型预测的对象非常广泛, 狭义的“物种”包括濒危物种 (Kumar \& Stohlgren, 2009; Matyukhina et al., 2015)、入侵物种(Padalia et al., 2014; 张熙鷔等, 2014)和传染病原(Feidas et al., 2014)等, 广义的“物种”则涉及珍稀动物的栖息地或 生境(侯宁等, 2014; 颜文博等, 2015)、梯田等农业景 观(Galletti et al., 2013)和森林破坏(Souza \& Marco, 2014)等生态退化过程, 预测尺度包括小尺度、中尺 度或大尺度, 在样本量很小 $(<20)$ 的情况下也有良好
效果(Kumar \& Stohlgren, 2009)。值得注意的是, 在 气候数据完整的情况下, MaxEnt模型还可投射到史 前地质时期(末次间冰期、末次盛冰期和全新世中期 等), 在谱系地理学研究中提供与遗传学、孢粉学、 古生物学证据独立的额外信息。将MaxEnt模型同时 应用于冰期和间冰期时, 研究人员可结合ArcGIS软 件识别气候变迁过程中生态稳定性高的地区，推断 物种避难所位置(Chan et al., 2011), 也可将物种分 布模型转换为生境阻力模型, 运用最小成本路径法 等算法识别物种迁移路线(于海杪等, 2014); 当单独 应用于冰期时, 可通过识别适宜度较高的地区辅助 推断可能的避难所位置(白伟宁和张大勇, 2014), 进 而从生态位模型角度对分子谱系地理学研究结论给 予佐证(Chen et al., 2012; Shi et al., 2014; Wang et al., 2015; Zhang et al., 2015)。因此, MaxEnt模型在进 化生物学、谱系地理学、保护生物学和生态学等领 域有着广泛的应用。

小叶柇(Quercus chenii)为中国特有的落叶栋 类、华东植物区系代表树种之一(祁承经, 1984), 是 研究地方区系形成、演化历史的重要材料。其生态、 经济价值也很高, 木材密度大于 $0.8 \mathrm{~g} \cdot \mathrm{cm}^{-3}$, 抗压强 度和硬度高, 是优良的硬质用材树种(汪师孟和夏 美君, 1986); 根系发达, 萌芽力强, 耐干旱瘦薄, 是 优良的水土保持树种; 生物量大, 燃烧热值高, 是 优良的薪炭林树种(北京林业大学落叶栋树研究组, 1988; 王连珍等, 2013)。科学营建小叶柇林对于调 整我国单一的人工林林种结构、提高人工林生物多 样性、促进林业可持续发展有着重要意义。但目前 关于小叶栋的研究报道尚少, 多集中于地理分布 (王良民等, 1985)、木材特性(汪师孟和夏美君, 1986) 和繁殖技术(胡婉仪和涂炳坤, 1992)等, 以往学者曾 使用Bioclim模型预测其潜在分布区(田佳倩, 2007), 但该模型与MaxEnt相比性能较差(Elith et al., 2006; Tsoar et al., 2007), 且过去和未来气候变迁背景下 小叶栋分布格局如何变化? 限制地理分布的主要气 
候因子是什么? 这些因子如何引起地理分布改变? 这些问题尚未解决, 依旧制约着小叶栋种质资源保 护、管理工作的科学开展。

本研究基于MaxEnt模型预测小叶栎在末次盛 冰期、全新世中期、现代(1950-2000年)和2070年的 潜在分布区, 利用多元环境相似度面(multivariate environmental similarity surface, MESS)和最不相似 变量(the most dissimilar variable, MoD)分析探讨气 候变迁过程中环境异常区域和引起潜在地理分布改 变的关键因素, 综合应用贡献率(percent contribution)及置换重要值(permutation importance)比较、 Jackknife检验评估制约现代地理分布的主要因子, 采用响应曲线(response curves)确定环境变量的适 宜区间, 以期重建冰期以来小叶柇地理分布格局的 变迁历史, 了解环境因子对潜在地理分布的制约机 制, 为小叶标种质资源保护和管理提供科学依据, 也为华东植物区系或麻柇组物种形成演化研究奠定 理论基础。

\section{1 材料和方法}

\section{1 研究区域}

小叶栋仅产于中国, 为落叶栋类中的中布型 (北京林业大学落叶柇树研究组, 1988)或南方广布 型(刘茂松和洪必恭, 1999)。其天然分布北界自河南 沿伏牛山、桐柏山、大别山直至安徽、江苏南部山 丘, 南界为南岭以北的湖南、江西南部低山丘陵, 东 界为浙江天目山至福建西部丘陵, 西界为云贵高原 东缘的湖南西部山区。小叶柇在华东植物区系常见, 至华中植物区系渐趋不见(吴征镒, 1979), 两区分界 线(湖北宜昌至湖南邵阳一线)一带如湖南桃源、道 县(吴诗霞等, 2011)有天然分布, 故其分布西界也可 认为是华东到华中植物区的过渡带。小叶柇天然分 布区的地理坐标范围为 $111.0^{\circ}-121.5^{\circ} \mathrm{E}, 25.0^{\circ}-32.5^{\circ}$ $\mathrm{N}$, 考虑到为科学引种提供参考, 以 $70^{\circ}-140^{\circ} \mathrm{E}, 17^{\circ}-$ $57^{\circ} \mathrm{N}$ 为预测区域。

\section{2 样本数据的搜集与篮选}

笔者于2014-2015年对安徽、江苏、浙江、江西、 湖南、湖北六省的小叶柇天然居群进行了实地调查, 搜集分布记录 16 条; 查阅已出版的文献资料, 搜集 小叶柇分布记录20条; 检索全球生物多样性信息网 络 (http://www.gbif.org)、中国数字植物标本馆 (http://www.cvh.org.cn)、教学标本资源共享平台 (http://mnh.scu.edu.cn/main.aspx)和中国植物图像库 (http://www.plantphoto.cn/), 分别搜集小叶栋标本记 录34条、232条、287条和59条，合计648条。参照李 圭等(2014)的方法确定标本地理坐标并对全部分布 记录进行篮选, 去除人工引种栽培记录, 考虑到气 候数据精度为 $2.5^{\prime}$, 为尽量降低群集效应带来的误 差, 在每个 $2.5^{\prime} \times 2.5^{\prime}$ 网格中只取唯一分布点, 最终 得到有效样本 55 个(附录I)。

\section{3 环境变量篮选和数据处理}

末次盛冰期、全新世中期、现代和未来气候数 据均下载自 WorldClim数据库(http://worldclim.org), 空间分辨率为 $2.5^{\prime}$ 。现代气候数据以 1950-2000年全 球不同气象站的每月气象数据为基础, 在空间分辨 率为 $30^{\prime \prime}$ 的网格内经插值法生成(Hijmans et al., 2005); 末次盛冰期、全新世中期、2070年气候数据 采用通用气候系统模式CCSM4生成, 其中未来温 室气体排放情景为典型浓度目标8.5 (RCP 8.5), 该 情景假定人口最多、技术革新率较低、能源改善缓 慢, 长时间内能源需求较高, 至2100年辐射强迫上 升至 $8.5 \mathrm{~W} \cdot \mathrm{m}^{-2}$ (王绍武等, 2012)。

每个时间段的原始气候数据包括 19 个生物气候 变量, 它们在解释植物生理生态耐受性方面有着良 好效果(Hijmans et al., 2005)。利用DIVA-GIS软件提 取 55 个样本点的 19 个现代气候变量数值, 采用皮尔 逊相关系数 $(r)$ 检验气候变量之间的多重共线性 (Yang et al., 2013), 在一组相关性很高 $(r>0.8)$ 的气 候变量中, 仅选择一个与物种分布关联紧密或便于 模型解释的变量用于模型预测(Kumar \& Stohlgren, 2009 ), 筛选得到 8 个环境变量(表1)。最终用于模型 预测的环境图层数据包括 4 个时间段的 32 个文件, 经ArcGIS 10.0软件转换为MaxEnt软件可用的ASCII 格式。

\section{4 模型预测和准确性评价}

用MaxEnt 3.3.3k软件(http://www.cs.princeton. edu/ schapire/maxent) 预测不同时期小叶柇潜在分 布区，重复10次。用交叉验证(cross-validation)方法 抽取测试样本。该方法将全部分布记录随机分为 10 个子集, 每次重复依次使用其中 1 个子集作为验证 集(test set), 剩余 9 个子集作为训练集(train set), 数 据利用度高。软件其余参数保持默认设置。最终输 出的ASCII文件是 10 次重复的平均值, 栅格数值为 以逻辑值形式给出的生存概率。将其导入ArcGIS 
表1 环境变量及其贡献率和适宜区间

Table 1 Environmental variables and their contributions and suitable value ranges

\begin{tabular}{|c|c|c|c|c|c|}
\hline $\begin{array}{l}\text { 代码 } \\
\text { Code }\end{array}$ & $\begin{array}{l}\text { 环境变量 } \\
\text { Environmental variable }\end{array}$ & $\begin{array}{l}\text { 单位 } \\
\text { Unit }\end{array}$ & $\begin{array}{l}\text { 贡献率 } \\
\text { Percent contribution } \\
(\%)\end{array}$ & $\begin{array}{l}\text { 置换重要值 } \\
\text { Permutation importance } \\
(\%)\end{array}$ & $\begin{array}{l}\text { 适宜区间 } \\
\text { Suitable range }\end{array}$ \\
\hline bio9 & 最干季平均气温 Mean temperature of driest quarter & ${ }^{\circ} \mathrm{C}$ & 1.5 & 51.0 & $1.0-14.9$ \\
\hline bio4 & 气温季节变化(标准偏差) Temperature seasonality (standard deviation) & ${ }^{\circ} \mathrm{C}$ & 23.3 & 23.0 & $6.7-9.6$ \\
\hline bio18 & 最暖季降水量 Precipitation of warmest quarter & $\mathrm{mm}$ & 4.8 & 12.1 & $430-830$ \\
\hline bio15 & 降水季节变化(变异系数) Precipitation seasonality (coefficient of variation) & $\%$ & 15.4 & 8.2 & $41.0-66.8$ \\
\hline bio1 & 年平均气温 Annual mean temperature & ${ }^{\circ} \mathrm{C}$ & 3.6 & 3.8 & $11.9-20.8$ \\
\hline bio12 & 年降水量 Annual precipitation & $\mathrm{mm}$ & 49.7 & 1.7 & $1050-2520$ \\
\hline bio3 & 等温性 Isothermality & $\%$ & 1.6 & 0.1 & $21.7-32.7$ \\
\hline bio8 & 最湿季平均气温 Mean temperature of wettest quarter & ${ }^{\circ} \mathrm{C}$ & 0.1 & 0.1 & $17.1-29.6$ \\
\hline
\end{tabular}

10.0 软件后采用平均间隔法将适宜度分为 5 级, 某点 的适宜度为该点的逻辑值占整个预测区域内最高逻 辑值的百分比, 以最高逻辑值的 $80 \%-100 \%$ 为高度 适宜区， $60 \%-80 \%$ 为中度适宜区， $40 \%-60 \%$ 为一般 适宜区，20\%-40\%为低度适宜区，0-20\%为不适宜 区，统计各级栅格数量计算面积变化的百分比。

使用受试者工作特征曲线 (receiver operator characteristic curves, ROC curves)对模型的准确性进 行评价。该曲线以预测结果的每一个值作为可能的 判断阈值, 计算得到相应的灵敏度和特异度, 以假 阳性率即(1-特异度)为横坐标, 以真阳性率即灵敏 度为纵坐标。曲线下的面积(AUC)因不受判断阈值 的影响, 可用于不同模型的比较, 因而成为目前公 认的诊断试验最佳评价指标(Phillips et al., 2006; 王 运生等, 2007)。AUC值的取值范围为 $[0,1]$, 值越大 表示模型判断力越强, 衡量标准为 $0.7-0.8$ 较准确, 0.8-0.9很准确, 0.9-1.0极准确。

\section{5 多元环境相似度面和最不相似变量分析}

以小叶栎现代天然分布区 $\left(111.0^{\circ}-121.5^{\circ} \mathrm{E}\right.$, $\left.25.0^{\circ}-32.5^{\circ} \mathrm{N}\right)$ 的环境变量为参考图层, 采用多元环 境相似度面和最不相似变量分析探讨过去和未来情 境中的气候异常区域和引起潜在地理分布改变的关 键因素。令 $\min _{i}$ 和 $\max _{i}$ 为环境变量 $V_{i}$ 在参考图层中的 最大值和最小值, $p_{i}$ 为某一情境中环境变量 $V_{i}$ 在研究 区域内某一点 $P$ 上的值, $f_{i}$ 是参考图层中环境变量 $V_{i}$ 小于 $p_{i}$ 的点的百分比, 如果 $f_{i}=0$, 那么相似度为 100 $\left(p_{i}-\min _{i}\right) /\left(\max _{i}-\min _{i}\right)$; 如果 $0<f_{i} \leqslant 50$, 那么相似 度为 $2 f_{i}$; 如果 $50<f_{i}<100$, 那么相似度为 $2(100-$ $\left.f_{i}\right)$; 如果 $f_{i}=100$, 那么相似度为 $100\left(\max _{i}-100\right) /$ $\left(\max _{i}-\min _{i}\right)$ 。最终 $P$ 点的多元相似度为各变量相似 度中的最小值, 该变量则为最不相似变量。多元相
似度如果是负值, 表明该点至少有一个变量的数值 超出了参考图层范围, 称之为气候异常点, 以红色 表示; 如果是正值, 那么以蓝色表示, 得分 100 表示 该点气候完全正常(Elith et al., 2010)。该操作在命令 窗口运行 maxent. jar文件中的density.tools. Novel工 具实现。

\section{6 环境变量的重要性评估}

综合使用贡献率、置换重要值和Jackknife检验 来评估环境变量在限制小叶係现代地理分布格局中 的重要性。贡献率依赖于求取最优解的特定途径, 通过逐步修正单一要素的系数来提高增益值, 将增 益值增额分配给决定该要素的环境变量, 并将其转 化为百分比后给出。在用贡献率评估环境变量的重 要性时, 如果存在高相关性变量, 评估结果可能难 以反映真实情况。置换重要值与具体算法无关, 仅 取决于最终结果, 通过随机置换训练点集(包括存 在点和背景点)上环境变量的数值并测定由此导致 的训练AUC值降低幅度, 经归一化后以百分比形式 给出。Jackknife检验则通过依次使用某一变量或依 次排除某一变量来创建一系列新的模型, 比较模型 间正则化训练增益(regularized training gain)、测试增 益(test gain)和AUC值的差异来评估环境变量的重 要性。

\section{7 响应曲线分析}

当模型只使用一个变量运行时, 适宜度随着变 量的改变而改变, 以该变量为横坐标, 以适宜度为 纵坐标, 得到单变量响应曲线。以每次重复中区域内 最高逻辑值的 $20 \%$ 作为阈值, 将单变量响应曲线中 阈值点对应的变量平均值作为小叶栋适宜生长条件 的上下限，据此确定每一环境变量的适宜范围。当模 型使用全部变量运行, 但仅某一变量改变, 其余变 
量均取分布点上的平均值时, 得到边缘响应曲线。

\section{2 结果}

\section{1 模型的准确性}

基于55条分布记录利用MaxEnt模型对小叶栎 现代潜在分布区进行预测, 10 次重复的训练AUC值 的最大值为 0.9896 , 最小值为 0.9882 , 平均值为 0.9887 ( \pm 0.0005 , 标准偏差), 测试AUC值的最大 值为 0.9943 , 最小值为 0.9810 , 平均值为 0.9869 $( \pm 0.0045$, 标准偏差), 表明模型预测极准确。

\section{2 现代潜在分布区}

55 条分布记录的平均逻辑值为 0.56 , 最高值为 0.83 (江西鄱阳), 最低值为 0.07 (河南桐柏), 分别属 于高度适宜区、中度适宜区、一般适宜区、低度适 宜区和不适宜区的分布点比例为 $32.7 \%$ 、27.3\%、 $27.3 \% 、 9.1 \%$ 和 $3.6 \%$ 。适宜分布区涵盖浙江、江西、 湖南大部, 江苏和安徽南部, 湖北西部和南部, 福 建北部, 河南南部、广东北部、广西北部少数地区 和重庆局部。高度适宜区为安徽南部、浙江西部、 江西东北部和湖北东部, 包括黄山、九华山、天目 山、怀玉山、大别山南坡、幕阜山北坡和鄱阳湖平
原等。此外, 朝鲜半岛南端和日本西端局部地区也 可能适宜小叶栎生存(图1C)。

\section{3 过去和未来潜在分布区}

在末次盛冰期，小叶栋高度适宜区显著东移， 位于江苏、浙江以东的东海大陆架内; 大陆架边缘 为中度至低度适宜区; 现代适宜区在当时适宜度降 低，原有高度适宜区变为中度乃至不适宜区(图 $1 \mathrm{~A})$ 。在全新世中期，除湖南西南部适宜度降低和现 代适宜区北界外侧适宜度略有升高外，小叶栋潜在 分布区轮廓与现代近似; 高度适宜区分散于湖北西 部、江西北部、浙江西部和湖南局部; 中度适宜区 面积比现代增加近54\% (图1B)。在2070年，小叶柇 潜在分布区将整体北移; 高度适宜区则向东、东北、 西南方向扩张, 面积增加 $64 \%$, 江西东北部变为中 度乃至不适宜区; 中度适宜区向北、东、西南方向 扩张，面积增加 $138 \%$ (图1D)。

\section{4 多元环境相似度面和最不相似变量分析}

在末次盛冰期、全新世中期和2070年，小叶栎 55 个现代分布点的平均多元相似度分别为 -0.72 、 2.37 和 -3.92 , 多元相似度为负值的点比例分别为 $31 \% 、 22 \%$ 和 $47 \%$ ，表明 2070 年气候异常程度最高，
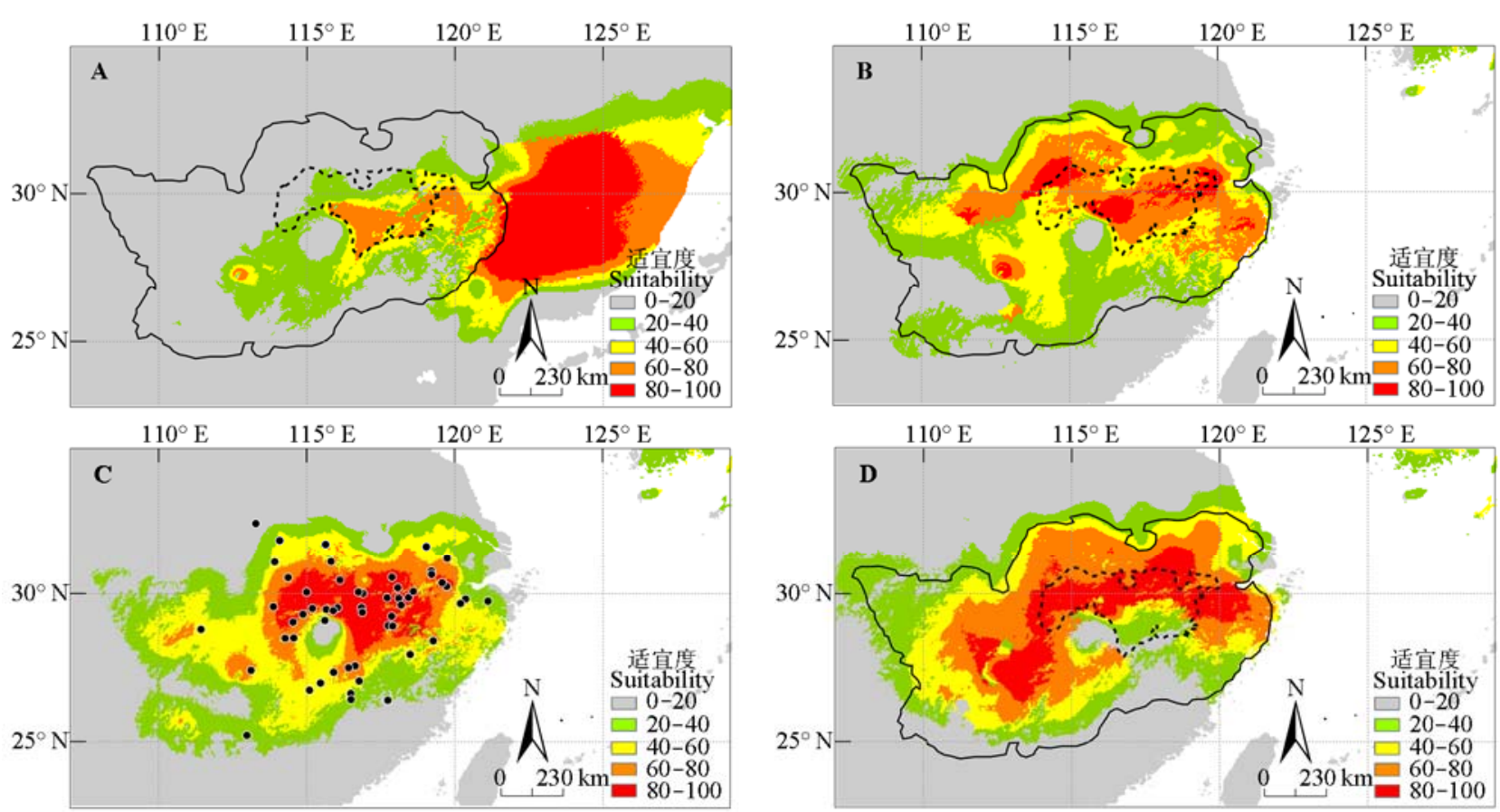

图1 小叶栋现代分布点(黑色点)和MaxEnt模型预测的不同历史时期潜在分布区。实线代表现代适宜区轮廓，虚线代表现代高 度适宜区轮廓。 $\mathbf{A}$, 末次盛冰期。 $\mathbf{B}$, 全新世中期。 C, 现代。 D, 2070年。

Fig. 1 Extant occurrence points (black dots) and potential distribution for Quercus chenii during different periods predicted by the MaxEnt model. The solid line and dashed line represent the outline of modern suitable area and highly suitable area, respectively. A, Last Glacial Maximum. B, Mid-Holocene. C, Present. D, In 2070. 
末次盛冰期次之, 全新世中期气候异常程度最低。 在末次盛冰期, 现代适宜区内的主要气候异常区域 出现在东北部和南端, 最不相似变量分别为气温季 节变化和降水季节变化。在全新世中期, 现代适宜 区内的主要气候异常区出现在北部, 最不相似变量 为气温季节变化。在2070年, 现代适宜区内的主要 气候异常区出现在北部和南部, 最不相似变量分别 为最湿季平均气温和降水季节变化(图2)。

\section{5 环境变量的重要性}

表 1 表明, 贡献率排前三位的变量为年降水量、 气温季节变化和降水季节变化，累积值为 $88.4 \%$;
置换重要值排前三位的变量为最干季平均气温、气 温季节变化和最暖季降水量，累积值为 $86.1 \%$ 。图3 表明, 仅使用单独变量时，正则化训练增益和测试 增益最高的 3 个变量依次为最干季平均气温、年平均 气温和最暖季降水量, $\mathrm{AUC}$ 值最高的 3 个变量依次 为最干季平均气温、气温季节变化和年平均气温, 表明这些变量包含更多的有效信息; 使用除此变量 以外的其他变量时, 正则化训练增益、测试增益和 AUC 值降低最多的 3 个变量依次为气温季节变化、 降水季节变化和最暖季降水量, 表明这些变量包含 更多其他变量所不具有的信息。综合来看, 影响小
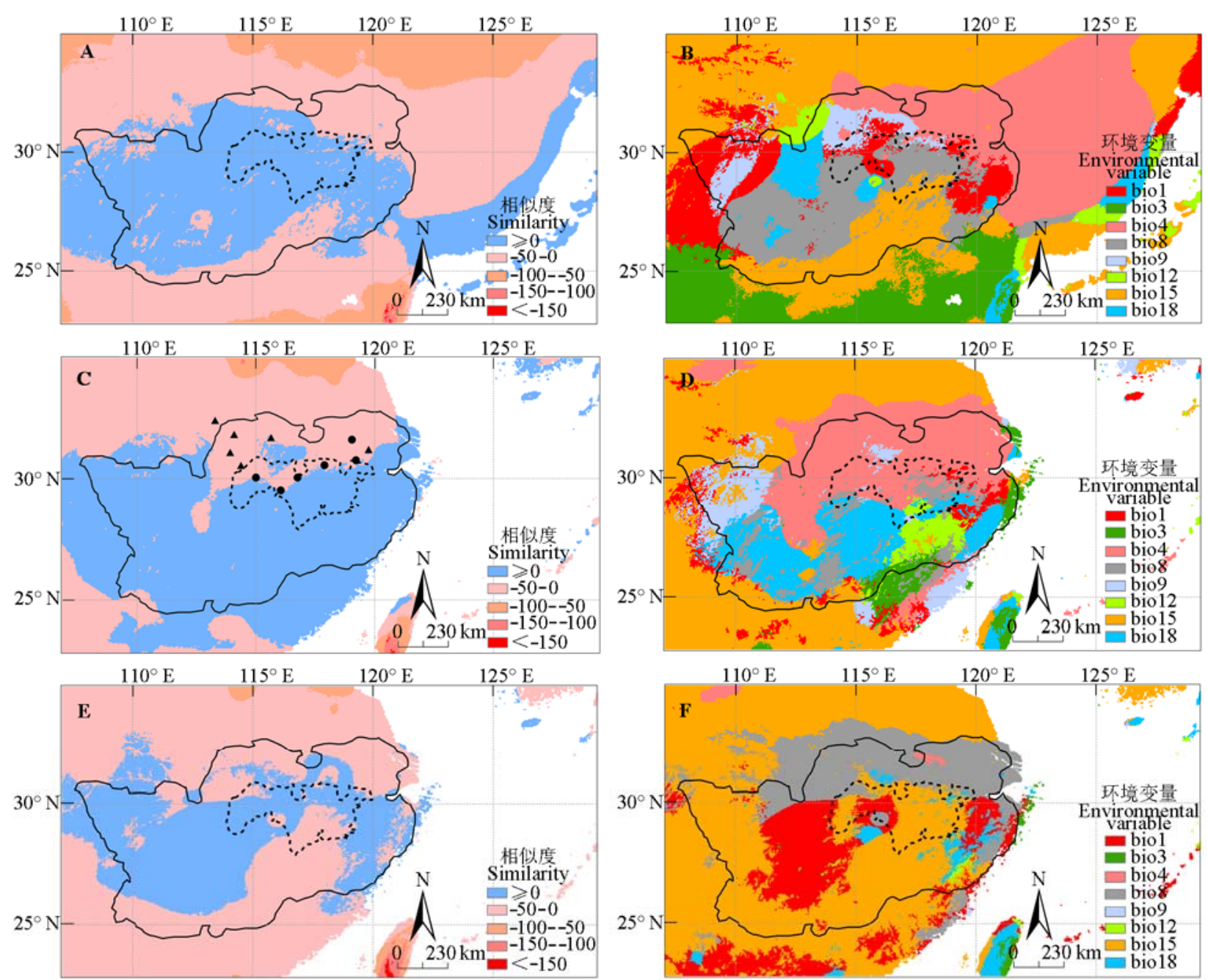

图2 小叶柇不同时期的多元环境相似度面(MESS)和最不相似变量(MoD)。实线代表现代适宜区轮廓，虚线代表现代高度适 宜区轮廓。图2 $\mathrm{C}$ 中, 圆形代表适宜度比现代低的气候异常点, 三角形代表适宜度比现代高的气候异常点。A, 末次盛冰期 MESS。 B, 未次盛冰期MoD。C, 全新世中期MESS。D, 全新世中期MoD。E, 2070年MESS。F, 2070年MoD。环境变量代码 同表1。

Fig. 2 Multivariate environmental similarity surface (MESS) and the most dissimilar (MoD) variable analysis for Quercus chenii during different periods. The solid line and dashed line represent the outline of modern suitable area and highly suitable area, respectively. In Fig. 2C, the circles represent novel climate points with suitability lower than present, and the triangles represent novel climate points with suitability higher than present. A, MESS for the Last Glacial Maximum (LGM). B, MoD for LGM. C, MESS for mid-Holocene. D, MoD for mid-Holocene. E, MESS for 2070. F, MoD for 2070. The codes of environmental variables see Table 1. 

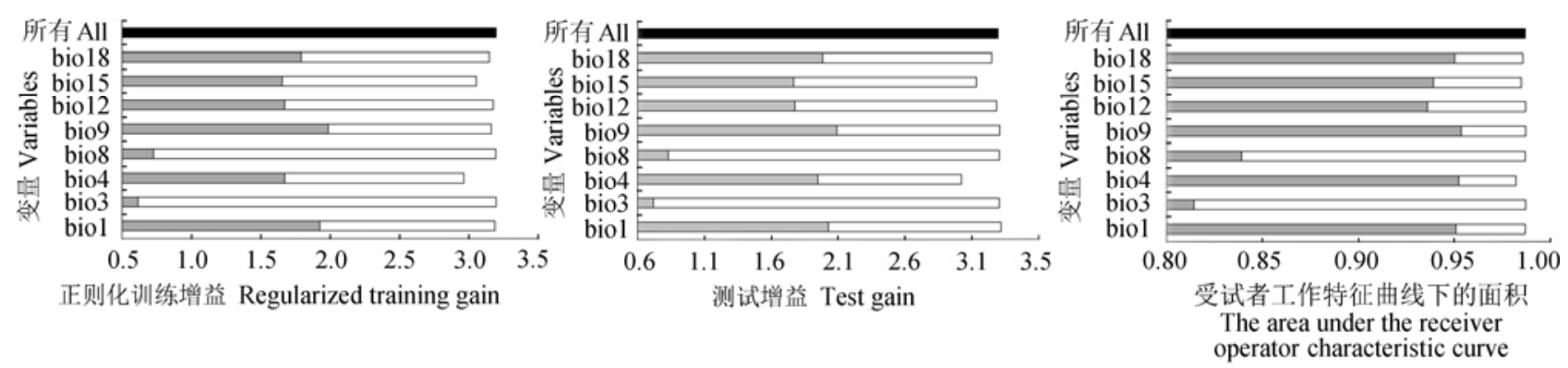

图3 环境变量重要性的Jackknife检验。灰色、白色、黑色条形图分别表示使用单独变量、除该变量外的所有变量和所有变 量用于模型预测。变量代码同表1。

Fig. 3 Jackknife test of the importance of variables. Grey, white, and black bars represent running the MaxEnt model with only the variable, without the variable and with all variables, respectively. The codes of variables see Table 1.

叶栋现代地理分布的主要因子为气温因子(气温季 节变化、最干季平均气温和年平均气温)和降水因子 (最暖季降水量、降水季节变化和年降水量)。

\section{6 响应曲线分析}

8 个变量的边缘响应曲线和单变量响应曲线见 附录II和附录III。单变量响应曲线均呈单峰型, 即随 着变量增大, 适宜度不断升高, 当达到最高值后, 适宜度又不断降低, 小叶楿的适宜生长条件如表1 所示。

\section{3 讨论和结论}

\section{1 四个时期潜在分布区的变化}

MaxEnt预测小叶柇在末次盛冰期的高度适宜 区位于东海大陆架。当时东海海平面下降120-130 $\mathrm{m}$ 左右, 绝大部分大陆架露出海面。许多学者通过 冲绳海槽钻孔孢粉分析来揭示该地区的古植被和古 环境状况。徐红艳等(2009)研究显示冰期时大陆架 上发育了以蒿属(Artemisia)为主的草地植被, 周边 可能存在包括落叶栋在内的稀疏落叶阔叶林。郑卓 等(2013)研究表明末次盛冰期时东海大陆架可能是 巨大的长江冲积平原, 但并非由半干旱地带性草原 所覆盖, 而是以泛滥平原草地和隐域性湿地为主, 在丘陵区有亚热带-温带林木的分布。而在中国东 部, 末次盛冰期时草原南界已到达长江三角洲以南 和浙江北部(刘金陵和王伟铭, 2004), 江汉平原阔叶 类栋属虽然一直存在, 但有所减少(李文渏, 1998), 太湖地区2.1-1.5万年前为森林草原-草原或干草原 植被(方炎明等, 2011), 所以在末次盛冰期东海陆架 有可能成为小叶柇的高度适生区。至全新世中期气 候趋于暖湿, 在9 ka BP中国南方植被与气候就有可 能接近现代, 亚热带落叶阔叶林迅速发展(李文渏,
1998), 孢粉证据表明, 巢湖地区在8 250-7 550年前 栋属达到极盛, 并于6 050-3 750年前经历波动后重 新恢复(Chen et al., 2009), 鄱阳湖地区在全新世中 期发展了以栋属(Quercus)、锥属(Castanopsis)和枫 香树属(Liquidambar)为主的森林(Jiang \& Piperno, 1999), 所以小叶柇也可能在该时期恢复生长。

田佳倩(2007)曾使用Bioclim模型预测小叶栎的 现代潜在分布, 揭示其核心分布区为长江中下游地 区，现代分布格局相对稳定，本文结果与其一致。 此外, 本文作者还指出在种源传播不受阻碍的情况 下, 小叶栋有可能向贵州、重庆以及四川东部等潜 在边缘分布区扩展。在未来温室气体排放情景为 RCP 8.5 时, MaxEnt预测小叶栋潜在分布区整体北 移, 面积扩大。这是因为作为一种喜暖湿树种, 未来 气温和降水的增加可能为其提供了更适宜的生长环 境。相关研究也表明蒙古扁桃(Amygdalus mongolica)在2020年、2050年和 2080 年的潜在分布面积分 别是当前分布面积的 $176 \%$ 、137\%和 $142 \%$ (马松梅 等, 2014), 马尾松分布区将逐渐向北迁移且面积将 逐渐增加(张雷等, 2011)。但预测植物潜在分布还需 结合土壤、地形、植被和竞争者等因素, 综合生物 与非生物因子, 才能有效地揭示小叶柇的未来潜在 适宜区。

\section{2 气候因子对现代地理分布的制约}

麻栋(Quercus acutissima)、栓皮栋(Q. variabilis) 与小叶栎同属柇属麻柇组, 但前两者均为东亚广布 型, 而小叶楿分布狭窄, 表明小叶栎与麻栋和栓皮 栋的生态适应性有显著区别。MaxEnt分析结果显示 气温和降水因子共同限制小叶标潜在地理分布格 局, 在本研究的 8 种评估途径中气温因子重要性列 入第一位7次，第二位5次，而降水因子列入第一位 
1 次, 第二位 3 次, 所以相对来说气温因子比降水因 子影响更大。田佳倩(2007)曾对16种落叶栋的水热 指标进行主成分分析, 也发现热量(气温)是在大尺 度上决定落叶栎类地理分布的首要气候因子, 水分 (降水)次之, 本文结论与之一致。

置换重要值和仅使用单独变量的Jackknife检验 均提示最干季平均气温是影响小叶栋潜在地理分布 的首要因素, 相关分析表明最干季平均气温与最冷 季平均气温具有极显著相关性, 相关系数为 0.71 $(p<0.01)$, 两者均可指示冬季陆地的寒冷程度。田 佳倩(2007)同样发现寒冷指数和最冷月最低气温在 落叶柇类南方广布型种的第一主成分中具有较高的 因子载荷。综合结果说明冬季低温可能是制约小叶 栎向北扩散的关键因子, 低温限制了小叶栋的种子 萌发或生长季长度, 寒冷逆境也对其耐寒能力提出 了严峻的考验, 最终导致其在北方地区难以正常生 长发育。在我国东部, 从热带、亚热带到温带气温 变化逐渐剧烈, 以最高逻辑值的 $20 \%$ 为阈值时, 气 温季节变化(标准差)适宜区间为6.7-9.6。接近于中 亚热带或北亚热带, 表明气温季节变化处于中等水 平时适宜小叶栋生长。

MaxEnt分析结果还显示年降水量的贡献率最 高, 而降水季节变化包含了较多其他变量所不具有 的信息; 基于倪健和宋永昌(1998)的方法计算得到 小叶柇的温暖指数 $(W I)$ 为 148 , 湿润指数 $(H I)$ 为 10 , 属于低中温湿润型(WI 140-160; HI 9-12), 同类树 种大多分布于我国东部湿润常绿阔叶林中部和北部 亚地带。这说明虽然气温在制约小叶栋分布方面起 主要作用, 但降水因子也不能忽视。

\section{3 气候因子与地理分布变迁的关联}

2070年气候异常程度最高, 最湿季平均气温、 年平均气温成为湖南东部、湖北东部、安徽中部、 浙江中部、江苏南部的最不相似变量, 与此同时, 这 些区域内的适宜度普遍升高, 以致高度适宜区面积 增加 $64 \%$, 中度适宜区面积增加 $138 \%$, 说明未来气 温的升高可能有利于小叶栋分布区的扩大, 年平均 气温的边缘响应曲线(附录II)也表明, 随着气温的升 高, 适宜度不断升高。末次盛冰期气候异常程度中 等, 多种因素的改变导致现代分布区的适宜度普遍 降低, 其中北部主要与气温季节变化有关, 中部主 要与年平均气温和最湿季平均气温有关, 南部主要 与降水季节变化有关。全新世中期气候异常程度最
低, 北部主要受气温季节变化影响, 而南部主要受 最暖季降水影响。总体来看, 现代分布区北部和南 部的适宜度变化分别与气温、降水因子关系更密切。

但是, 气候因子并非相互独立地影响适宜度。 多元环境相似性面和最不相似变量分析表明, 在末 次盛冰期、全新世中期和2070年，现代适宜区内气 候异常的关键因子是气温季节变化、降水季节变化 和最湿季平均气温。以气温季节变化为例, 其边缘 响应曲线(附录II)表明, 当取值较低或较高时, 该变 量不会影响适宜度, 而在一定范围内, 随着取值的 增加, 适宜度不断升高。但在实际情况中, 如在全新 世中期, 现代适宜区北部6个气候异常分布点气温 季节变化平均升高 $9.2 \%$, 适宜度也平均升高 $33.2 \%$, 而另外 6 个气候异常分布点气温季节变化升高 $9.0 \%$, 适宜度却下降 $20.3 \%$, 说明小叶柇地理分布变迁是 多因子综合作用的结果, 主导因子的作用效果受其 他因子影响。

\section{4 结论}

小叶栋有可能在麻栋组植物起源后扩散到现在 华东植物区系时分化形成, 末次盛冰期时主要集中 于东海大陆架上的落叶阔叶林中, 随着后期气候转 暖和海平面上升, 逐步退缩至中国南方, 形成麻栎 与其特有衍生种小叶栋共生的分布格局。气温因子 和降水因子共同影响小叶栎现代地理分布, 最干季 平均气温制约着小叶柇向北分布, 未来气候变暖可 能引起其适宜区扩张。气温季节变化和降水季节变 化代表着水热分布格局的改变, 小叶栋地理分布变 迁是多因素综合作用的结果。

基金项目 国家自然科学基金(31370666)、江苏高 校优势学科建设工程资助项目 (PAPD) 和江苏省研 究生培养创新工程项目 (KYLX15_0922)。

\section{参考文献}

Bai WN, Zhang DY (2014). Current status and future directions in plant phylogeography. Chinese Bulletin of Life Sciences, 26, 125-136. (in Chinese with English abstract) [白伟宁, 张大勇 (2014). 植物亲缘地理学的研究现状与发展趋 势. 生命科学, 26, 125-136.]

Bellard C, Bertelsmeier C, Leadley P, Thuiller W, Courchamp F (2012). Impacts of climate change on the future of biodiversity. Ecology Letters, 15, 365-377.

Chan LM, Brown JL, Yoder AD (2011). Integrating statistical genetic and geospatial methods brings new power to phylogeography. Molecular Phylogenetics and Evolution, 59, 
$523-537$.

Chen DM, Zhang XX, Kang HZ, Sun X, Yin S, Du HM, Yamanaka N, Gapare W, Wu HX, Liu CJ (2012). Phylogeography of Quercus variabilis based on chloroplast DNA sequence in East Asia: Multiple glacial refugia and mainlandmigrated island populations. PLOS ONE, 7, e47268. doi:10.1371/journal.pone.0047268.

Chen W, Wang WM, Dai XR (2009). Holocene vegetation history with implications of human impact in the Lake Chaohu area, Anhui Province, East China. Vegetation History \& Archaeobotany, 18, 137-146.

Elith J, Graham CH, Anderson RP, Dudík M, Ferrier S, Guisan A, Hijmans RJ, Huettmann F, Leathwick JR, Lehmann A, Li J, Lohmann LG, Loiselle BA, Manion G, Moritz C, Nakamura M, Nakazawa Y, Overton JM, Peterson AT, Phillips SJ, Richardson KS, Scachetti-Pereira R, Schapire RE, Soberón J, Williams S, Wisz MS, Zimmermann NE (2006). Novel methods improve prediction of species' distributions from occurrence data. Ecography, 29, 129-151.

Elith J, Kearney M, Phillips S (2010). The art of modelling range-shifting species. Methods in Ecology and Evolution, 1, 330-342.

Fang YM, Wang T, Zhang JC (2011). Analysis of quaternary vegetation changes along the Beijing-Hangzhou Grand Canal. Journal of Nanjing Forestry University (Natural Sciences), 35, 109-115. (in Chinese with English abstract) [方炎明，王挺，张金池 (2011). 京杭大运河沿线第四 纪植被变迁分析. 南京林业大学学报·自然科学版, 35 , 109-115.]

Feidas H, Kouam MK, Kantzoura V, Theodoropoulos G (2014). Global geographic distribution of Trichinella species and genotypes. Infection, Genetics and Evolution, 26, 255-266.

Galletti CS, Ridder E, Falconer SE, Fall PL (2013). Maxent modeling of ancient and modern agricultural terraces in the Troodos foothills, Cyprus. Applied Geography, 39, 46-56.

Hewitt GM (2004). Genetic consequences of climatic oscillations in the Quaternary. Philosophical Transactions of the Royal Society B: Biological Sciences, 359, 183-195.

Hijmans RJ, Cameron SE, Parra JL, Jones PG, Jarvis A (2005). Very high resolution interpolated climate surfaces for global land areas. International Journal of Climatology, 25, 1965-1978.

Hou N, Dai Q, Ran JH, Jiao YY, Cheng Y, Zhao C (2014). A corridor design for the giant panda in the Niba Mountain of China. Chinese Journal of Applied and Environmental Biology, 20, 1039-1045. (in Chinese with English abstract) [侯宁, 戴强, 由江洪, 焦迎迎, 程勇, 赵成 (2014). 相岭山系泥巴山大熊猫生境廊道设计. 应用与 环境生物学报, 20, 1039-1045.]

$\mathrm{Hu}$ WY, Tu BK (1992). Research on cutting propagation of
Quercus variabilis, Quercus acutissima, Quercus chenii, Castanopsis sclerophylla and Lithocarpus glaber. Hubei Forestry Science and Technology, (2), 35-36. (in Chinese) [胡婉仪, 涂炳坤 (1992). 栓皮栋、麻栋、小叶栋、苦槠、 石栎扦插繁殖简报. 湖北林业科技, (2), 35-36.]

Jiang Q, Piperno DR (1999). Environmental and archaeological implications of a late quaternary palynological sequence, Poyang Lake, Southern China. Quaternary Research, 52, 250-258.

Jiang ZH, Zhang X, Wang J (2008). Projection of climate change in China in the 21 st century by IPCC-AR4 Models. Geographical Research, 27, 787-799. (in Chinese with English abstract) [江志红, 张霞, 王冀 (2008). IPCCAR4模式对中国21世纪气候变化的情景预估. 地理研 究, 27, 787-799.]

Kumar S, Stohlgren TJ (2009). Maxent modeling for predicting suitable habitat for threatened and endangered tree Canacomyrica monticola in New Caledonia. Journal of Ecology and Natural Environment, 1(4), 94-98.

Li WY (1998). Vegetation and Environment of China During the Quaternary. Science Press, Beijing. (in Chinese) [李文猗 (1998). 中国第四纪植被与环境. 科学出版社, 北京.]

Li Y, Zhang XW, Fang YM (2014). Predicting the impact of global warming on the geographical distribution pattern of Quercus variabilis in China. Chinese Journal of Applied Ecology, 25, 3381-3389. (in Chinese with English abstract) [李圭, 张兴旺, 方炎明 (2014). 气候变暖对中国 栓皮柇地理分布格局影响的预测. 应用生态学报, 25, 3381-3389.]

Liu JL, Wang WM (2004). A discussion on the vegetation types during LGM time in South China. Quaternary Sciences, 24, 213-216. (in Chinese with English abstract) [刘金陵, 王伟铭 (2004). 关于华南地区末次冰盛期植被类型的 讨论. 第四纪研究, 24, 213-216.]

Liu MS, Hong BG (1999). The analysis of distribution pattern of Fagaceae in China. Journal of Nanjing Forestry University, 23(5), 18-22. (in Chinese with English abstract) [刘茂松, 洪必恭 (1999). 中国壳斗科的分布格局类型 分析. 南京林业大学学报, 23(5), 18-22.]

Ma SM, Nie YB, Geng QL, Wang RX (2014). Impact of climate change on suitable distribution range and spatial pattern in Amygdalu smongolica. Chinese Journal of Plant Ecology, 38, 262-269. (in Chinese with English abstract) [马松梅, 聂迎涁, 耿庆龙, 王荣学 (2014). 气候变化对蒙古扁桃 适宜分布范围和空间格局的影响. 植物生态学报, 38, 262-269.]

Matyukhina DS, Miquelle DG, Murzin AA, Pikunov DG, Fomenko PV, Aramilev VV, Litvinov MN, Salkina GP, Seryodkin IV, Nikolaev IG, Kostyria AV, Gaponov VV, Yudin VG, Dunishenko YM, Smirnov EN, Korkishko VG, Marino J (2015). Assessing the influence of environmental

www.plant-ecology.com 
parameters on Amur tiger distribution in the Russian far east using a MaxEnt modeling approach. Achievements in the Life Sciences, 8(2), 95-100.

Members of China Quaternary Pollen Data Base (2000). Pollenbased biome reconstruction at Middle Holocene (6ka BP) and Last Glacial Maximum (18 ka BP) in China. Acta Botanica Sinica, 42, 1201-1209. (in Chinese with English abstract) [中国第四纪孢粉数据库小组 (2000). 中国中 全新世(6 ka BP)和末次盛冰期(18 ka BP)生物群区的重 建. 植物学报, 42, 1201-1209.]

Ni J, Song CY (1998). Relationship between Kira's indexes and distribution of dominants and companions of subtropical evergreen broadleaved forest in China. Acta Ecologica Sinica, 18, 248-262. (in Chinese with English abstract) [倪 健, 宋永昌 (1998). 中国亚热带常绿阔叶林优势种及常 见种的分布与Kira指标的关系. 生态学报, 18, 248-262.]

Padalia H, Srivastava V, Kushwaha SPS (2014). Modeling potential invasion range of alien invasive species, Hyptis suaveolens (L.) Poit. in India: Comparison of MaxEnt and GARP. Ecological Informatics, 22, 36-43.

Phillips SJ, Anderson RP, Schapire RE (2006). Maximum entropy modeling of species geographic distributions. Ecological Modelling, 190, 231-259.

Qi CJ (1984). The fundamental pattern of the geographic distribution of vegetation in Hunan Province. Acta Botanica Yunnanica, 6, 403-416. (in Chinese with English abstract) [祁承经(1984). 湖南植被地理分布的基本规律. 云南植 物研究, 6, 403-416.]

Shi MM, Michalski SG, Erik W, Chen XY, Durka W (2014). Phylogeography of a widespread Asian subtropical tree: Genetic east-west differentiation and climate envelope modelling suggest multiple glacial refugia. Journal of Biogeography, 41, 1710-1720.

Souza RAD, Marco PD (2014). The use of species distribution models to predict the spatial distribution of deforestation in the western Brazilian Amazon. Ecological Modelling, 291, 250-259.

The Research Group of the Deciduous Oaks (1988). A synoptic summary of the researches on Chinese deciduous oaks. Journal of Beijing Forestry University, (3), 77-83. (in Chinese with English abstract) [北京林业大学落叶柇树 研究组 (1988). 中国落叶栎树的综合研究. 北京林业大 学学报, (3), 77-83.]

Tian JQ (2007). Differentiated Distribution of Deciduous Quercus spp. and Controlling Climatic Factors in China. Master degree dissertation, Institute of Botany, Chinese Academy of Sciences, Beijing. (in Chinese) [田佳倩 (2007). 落叶栎树在中国的地理替代分布及其气候制约. 硕士学位论文, 中国科学院植物研究所, 北京.]

Tsoar A, Allouche O, Steinitz O, Rotem D, Kadmon R (2007). A comparative evaluation of presence-only methods for modelling species distribution. Diversity and Distributions, 13, 397-405.

Wang LM, Ren XW, Liu YQ (1985). Geographic distribution of deciduous oaks in China. Journal of Beijing Forestry University, (2), 57-69. (in Chinese with English abstract) [王良民，任宪威，刘一樵 (1985). 我国落叶柇的地理 分布. 北京林业大学学报, (2), 57-69.]

Wang LZ, Lang QL, Xia XH, Sun J, Gao W, Li LF (2013). Research advances in oak germplasm resources. Science of Sericulture, 39, 805-811. (in Chinese with English abstract) [王连珍, 郎庆龙, 夏兴宏, 孙娟, 高伟, 李立峰 (2013). 柞树种质资源研究进展. 虫业科学，39，805811.]

Wang SM, Xia MJ (1986). Wood structure and some physicalmechanical properties of four Chinese oaks. Journal of Beijing Forestry University, (1), 53-61. (in Chinese with English abstract) [汪师孟, 夏美君 (1986). 中国栎属木 材的构造及物理-力学性质(三). 北京林业大学学报, (1), 53-61.]

Wang SW, Luo Y, Zhao ZC, Wen XY, Huang JB (2012). New generation of scenarios of greenhouse gas emission. Advances in Climate Change Research, 8, 305-307. (in Chinese with English abstract) [王绍武, 罗勇, 赵宗慈, 闻新 宇, 黄建斌 (2012). 新一代温室气体排放情景. 气候变 化研究进展, 8, 305-307.]

Wang YH, Jiang WM, Comes HP, Hu FS, Qiu YX, Fu CX (2015). Molecular phylogeography and ecological niche modelling of a widespread herbaceous climber, Tetrastigma hemsleyanum (Vitaceae): Insights into pliopleistocene range dynamics of evergreen forest in subtropical China. New Phytologist, 206, 852-867.

Wang YS, Xie BY, Wan FH, Xiao QM, Dai LY (2007). Application of ROC curve analysis in evaluating the performance of alien species' potential distribution models. Biodiversity Science, 15, 365-372. (in Chinese with English abstract) [王运生，谢丙炎，万方浩，肖启明，戴良英 (2007). ROC曲线分析在评价入侵物种分布模型中的应 用. 生物多样性, 15, 365-372.]

Wu SX, Tian J, Yu XL, Cao FX (2011). A preliminary study of the natural forest vegetationin the limestone regions of Southern Hunan. Journal of Central South University of Forestry \& Technology, 31(6), 55-64. (in Chinese with English abstract) [吴诗霞, 田径, 喻勋林, 曹福祥 (2011). 湘南石灰岩地区天然林植被初步研究. 中南林 业科技大学学报, 31(6), 55-64.]

Wu ZY (1979). The regionalization of Chinese flora. Acta Botanica Yunnanica, 1(1), 1-20. (in Chinese) [ 吴征镒 (1979). 论中国植物区系的分区问题. 云南植物研究, 1, $1-20$.

Xu HY, Chang FM, Luo YL, Sun XJ (2009). Palaeoenvironmental changes from pollen record in deep sea core PC-1 
from northern Okinawa Trough, East China Sea during the past 24 ka. Chinese Science Bulletin, 54, 3117-3126. (in Chinese) [徐红艳, 常凤鸣, 罗运利, 孙湘君 (2009). 冲

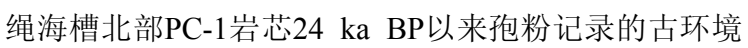
信息. 科学通报, 54, 3117-3126.]

Yan WB, Wang Q, Wang C (2015). Evaluation of potential breeding habitat distribution with Maxent model for crested ibis in the Qinling-Bashan region. Chinese Journal of Zoology, 50, 185-193. (in Chinese with English abstract) [颜文博, 王琦, 王超 (2015). 应用Maxent模型分析秦 巴地区朱鲄适宜繁殖地的分布. 动物学杂志, 50, 185-193.]

Yang XQ, Kushwaha SPS, Saran S, Xu J, Roy PS (2013). Maxent modeling for predicting the potential distribution of medicinal plant, Justicia adhatoda L. in Lesser Himalayan foothills. Ecological Engineering, 51, 83-87.

Yu HB, Zhang YL, Li SC, Qi W, Hu ZJ (2014). Predicting the dispersal routes of alpine plant Pedicularis longiflora (Orobanchaceae) based on GIS and species distribution models. Chinese Journal of Applied Ecology, 25, 16691673. (in Chinese with English abstract) [于海涁, 张镱锂, 李士成, 祁威, 胡忠俊 (2014). 基于GIS和物种分布模 型的高山植物长花马先蒿迁移路线模拟. 应用生态学 报, 25, 1669-1673.]

Zhang L, Liu SR, Sun PS, Wang TL (2011). Comparative evaluation of multiple models of the effects of climate change on the potentialdistribution of Pinus massoniana.
Chinese Journal of Plant Ecology, 35, 1091-1105. (in Chinese with English abstract) [张雷, 刘世荣, 孙鹏森, 王同立 (2011). 气候变化对马尾松潜在分布影响预估 的多模型比较. 植物生态学报, 35, 1091-1105.]

Zhang XA, Sui XY, Lü Z, Chen YF (2014). A prediction of the global habitat of two invasive fishes (Pseudorasbora par$v a$ and Carassius auratus) from East Asia using Maxent. Biodiversity Science, 22, 182-188. (in Chinese with English abstract) [张熙謷, 隋晓云, 吕植, 陈毅峰 (2014). 基于Maxent的两种入侵性鱼类(麦穗鱼和鲫)的全球适 生区预测. 生物多样性, 22, 182-188.]

Zhang XW, Li Y, Liu CY, Xia T, Zhang Q, Fang YM (2015). Phylogeography of the temperate tree species Quercus acutissima in China: Inferences from chloroplast DNA variations. Biochemical Systematics and Ecology, 63, 190197.

Zheng Z, Huang KY, Deng Y, Cao LL, Yu SH, Suc JP, Berne S, Guichard F (2013). A 200 ka pollen record from Okinawa Trough: Paleoenvironment reconstruction of glacialinterglacial cycles. Science China: Earth Sciences, 43, 1231-1248. (in Chinese) [郑卓, 黄康有, 邓皿, 曹玲珑, 余少华, Suc JP, Berne S, Guichard F (2013). 冲绳海槽 $200 \mathrm{ka}$ 的孢粉记录及冰期-间冰期旋回古环境重建. 中 国科学: 地球科学, 43, 1231-1248.]

责任编委：倪 健 责任编辑: 王 葳

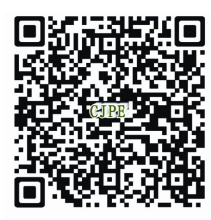

植物生态学报官网

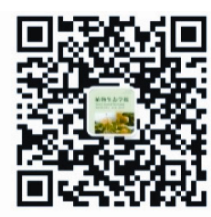

微信订阅号

期刊及学科 相关信息发布

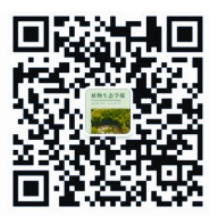

微信服务号

稿件状态查询 全文检索汶览 
附录I 用于模型预测的小叶栋分布记录

Appendix I Presence point records of Quercus chenii for model prediction

\begin{tabular}{|c|c|c|c|c|}
\hline 序号 & 居群位置 & 经度 & 纬度 & 来源 \\
\hline Code & Location of populations & Longitude & Latitude & Source \\
\hline 1 & 安徽省太湖县天华镇 & $116.13^{\circ} \mathrm{E}$ & $30.45^{\circ} \mathrm{N}$ & 实地调查 \\
\hline & Tianhua Town, Taihu County, Anhui Province & & & Field survey \\
\hline 2 & 安徽省东至县响岭村 & $116.91^{\circ} \mathrm{E}$ & $30.00^{\circ} \mathrm{N}$ & CVH PE 00296660 \\
\hline 3 & $\begin{array}{l}\text { 安徽省青阳县朱备镇 } \\
\text { Zhubei Town, Qingyang County, Anhui Province }\end{array}$ & $117.88^{\circ} \mathrm{E}$ & $30.55^{\circ} \mathrm{N}$ & CVH NAS 00203812 \\
\hline 4 & $\begin{array}{l}\text { 安徽省黄山市焦村镇 } \\
\text { Jiaocun Town, Huangshan City, Anhui Province }\end{array}$ & $118.08^{\circ} \mathrm{E}$ & $30.19^{\circ} \mathrm{N}$ & $\begin{array}{l}\text { 实地调查 } \\
\text { Field survey }\end{array}$ \\
\hline 5 & $\begin{array}{l}\text { 安徽省祁门县棕里村 } \\
\text { Zongli Village, Qimen County, Anhui Province }\end{array}$ & $117.72^{\circ} \mathrm{E}$ & $29.85^{\circ} \mathrm{N}$ & CVH NAS 00203826 \\
\hline 6 & $\begin{array}{l}\text { 安徽省歌县 } \\
\text { She County, Anhui Province }\end{array}$ & $118.44^{\circ} \mathrm{E}$ & $29.87^{\circ} \mathrm{N}$ & CVH NAS 00203796 \\
\hline 7 & $\begin{array}{l}\text { 安徽省休宁县齐云山 } \\
\text { Qiyun Mountain, Xiuning County, Anhui Province }\end{array}$ & $118.11^{\circ} \mathrm{E}$ & $29.84^{\circ} \mathrm{N}$ & $\begin{array}{l}\text { 实地调查 } \\
\text { Field survey }\end{array}$ \\
\hline 8 & $\begin{array}{l}\text { 安徽省休宁县五城镇 } \\
\text { Wucheng Town, Xiuning County, Anhui Province }\end{array}$ & $118.19^{\circ} \mathrm{E}$ & $29.61^{\circ} \mathrm{N}$ & CVH NAS 00203816 \\
\hline 9 & $\begin{array}{l}\text { 安徽省金寨县金刚台国家地质公园 } \\
\text { Jingangtai National Geopark, Jinzhai County, Anhui Province }\end{array}$ & $115.64^{\circ} \mathrm{E}$ & $31.68^{\circ} \mathrm{N}$ & Fang, 2012 \\
\hline 10 & $\begin{array}{l}\text { 安徽省金寨县天堂寨镇 } \\
\text { Tiantangzhai Town, Jinzhai County, Anhui Province }\end{array}$ & $115.82^{\circ} \mathrm{E}$ & $31.15^{\circ} \mathrm{N}$ & $\begin{array}{l}\text { 实地调查 } \\
\text { Field survey }\end{array}$ \\
\hline 11 & $\begin{array}{l}\text { 安徽省广德县金龙山 } \\
\text { Jinlong Mountain, Guangde County, Anhui Province }\end{array}$ & $119.21^{\circ} \mathrm{E}$ & $30.76^{\circ} \mathrm{N}$ & CVH NAS 00203814 \\
\hline 12 & $\begin{array}{l}\text { 安徽省广德县七里冲 } \\
\text { Qilichong, Guangde County, Anhui Province }\end{array}$ & $119.22^{\circ} \mathrm{E}$ & $30.65^{\circ} \mathrm{N}$ & CVH NAS 00203819 \\
\hline 13 & $\begin{array}{l}\text { 安徽省绩溪县华阳镇 } \\
\text { Huayang Town, Jixi County, Anhui Province }\end{array}$ & $118.60^{\circ} \mathrm{E}$ & $30.07^{\circ} \mathrm{N}$ & CVH NAS 00203813 \\
\hline 14 & $\begin{array}{l}\text { 福建省浦城县 } \\
\text { Pucheng County, Fujian Province }\end{array}$ & $118.50^{\circ} \mathrm{E}$ & $27.94^{\circ} \mathrm{N}$ & SRSPE $2151 \mathrm{C} 0001 \mathrm{H} 00006202$ \\
\hline 15 & $\begin{array}{l}\text { 福建省沙县洞天岩 } \\
\text { Dongtianyan, Sha County, Fujian Province }\end{array}$ & $117.74^{\circ} \mathrm{E}$ & $26.39^{\circ} \mathrm{N}$ & CVH PE 00296673 \\
\hline 16 & $\begin{array}{l}\text { 福建省泰宁县 } \\
\text { Taining County, Fujian Province }\end{array}$ & $115.10^{\circ} \mathrm{E}$ & $26.73^{\circ} \mathrm{N}$ & CVH PE 00296672 \\
\hline 17 & $\begin{array}{l}\text { 河南省桐柏县太白顶 } \\
\text { Taibaiding, Tongbai County, Henan Province }\end{array}$ & $113.29^{\circ} \mathrm{E}$ & $32.38^{\circ} \mathrm{N}$ & SRSPE $2151 \mathrm{C} 0001400004887$ \\
\hline 18 & $\begin{array}{l}\text { 河南省信阳市鸡公山 } \\
\text { Jigong Mountain, Xinyang City, Henan Province }\end{array}$ & $114.09^{\circ} \mathrm{E}$ & $31.81^{\circ} \mathrm{N}$ & Ye et al., 2014 \\
\hline 19 & $\begin{array}{l}\text { 湖北省大冶市 } \\
\text { Daye City, Hubei Province }\end{array}$ & $115.00^{\circ} \mathrm{E}$ & $30.05^{\circ} \mathrm{N}$ & SRSPE 2151C0001M07001199 \\
\hline 20 & $\begin{array}{l}\text { 湖北省武汉市珞珈山 } \\
\text { Luojia Hill, Wuhan City, Hubei Province }\end{array}$ & $114.38^{\circ} \mathrm{E}$ & $30.54^{\circ} \mathrm{N}$ & CVH WUK 0310424 \\
\hline 21 & $\begin{array}{l}\text { 湖北省崇阳县桂花林场 } \\
\text { Guihua Forest Farm, Chongyang County, Hubei Province }\end{array}$ & $113.88^{\circ} \mathrm{E}$ & $29.55^{\circ} \mathrm{N}$ & Lü et al., 2013 \\
\hline 22 & $\begin{array}{l}\text { 湖北省孝感市钱家垅 } \\
\text { Qianjialong, Xiaogan City, Hubei Province }\end{array}$ & $113.92^{\circ} \mathrm{E}$ & $31.07^{\circ} \mathrm{N}$ & CVH LBG 00066761 \\
\hline 23 & $\begin{array}{l}\text { 湖南省桃源县桃花源 } \\
\text { Taohuayuan, Tooyunty, Hunan Province }\end{array}$ & $111.44^{\circ} \mathrm{E}$ & $28.79^{\circ} \mathrm{N}$ & $\begin{array}{l}\text { 实地调查 } \\
\text { Field survey }\end{array}$ \\
\hline 24 & $\begin{array}{l}\text { 湖南省株洲县砖桥乡 } \\
\text { Zhuangiao Towship, Zhuzhou County, Hunan Province }\end{array}$ & $113.13^{\circ} \mathrm{E}$ & $27.40^{\circ} \mathrm{N}$ & $\begin{array}{l}\text { 实地调查 } \\
\text { Field survey }\end{array}$ \\
\hline 25 & $\begin{array}{l}\text { 湖南省宜章县栗源镇 } \\
\text { Liyuan Town, Yizhang County, Hunan Province }\end{array}$ & $112.99^{\circ} \mathrm{E}$ & $25.21^{\circ} \mathrm{N}$ & $\begin{array}{l}\text { 实地调查 } \\
\text { Field survey }\end{array}$ \\
\hline 26 & $\begin{array}{l}\text { 汇苏省南京市溧水林场 } \\
\text { Lishii Forest Farm, Nanjing City, Jiangsu Province }\end{array}$ & $119.04^{\circ} \mathrm{E}$ & $31.60^{\circ} \mathrm{N}$ & $\begin{array}{l}\text { 实地调查 } \\
\text { Field survey }\end{array}$ \\
\hline 27 & $\begin{array}{l}\text { 江苏省宜兴市馨山 } \\
\text { Qingshan Mountain, Yixing City, Jiangsu Province }\end{array}$ & $119.75^{\circ} \mathrm{E}$ & $31.19^{\circ} \mathrm{N}$ & CVH NAS 00102536 \\
\hline 28 & $\begin{array}{l}\text { 江西省广昌县塘坊乡 } \\
\text { Tangfang Township, Guangchang County, Jiangxi Province }\end{array}$ & $116.49^{\circ} \mathrm{E}$ & $26.62^{\circ} \mathrm{N}$ & CVH LBG 00018225 \\
\hline 29 & $\begin{array}{l}\text { 江西省乐安县茅岗村 } \\
\text { Maogang Vallige, Le'an County, Jiangxi Province }\end{array}$ & $115.91^{\circ} \mathrm{E}$ & $27.34^{\circ} \mathrm{N}$ & $\begin{array}{l}\text { 实地调查 } \\
\text { Field survey }\end{array}$ \\
\hline 30 & $\begin{array}{l}\text { 江西省黎川县河樟村 } \\
\text { Hezhang Vallige, Lichuan County, Jiangxi Province }\end{array}$ & $116.78^{\circ} \mathrm{E}$ & $27.04^{\circ} \mathrm{N}$ & CVH LBG 00018220 \\
\hline 31 & $\begin{array}{l}\text { 江西省南城县 } \\
\text { Nancheng County, Jiangxi Province }\end{array}$ & $116.64^{\circ} \mathrm{E}$ & $27.56^{\circ} \mathrm{N}$ & CVH KUN 504150 \\
\hline 32 & $\begin{array}{l}\text { 江西省宜黄县 } \\
\text { Yihung County, Jiangxi Province }\end{array}$ & $116.42^{\circ} \mathrm{E}$ & $27.49^{\circ} \mathrm{N}$ & PPBC 232584 \\
\hline 33 & $\begin{array}{l}\text { 江西省石城县丰山乡 } \\
\text { Fengshan Township, Shicheng County, Jiangxi Province }\end{array}$ & $116.50^{\circ} \mathrm{E}$ & $26.42^{\circ} \mathrm{N}$ & CVH LBG 00018202 \\
\hline 34 & $\begin{array}{l}\text { 江西省吉水县白沙镇 } \\
\text { Baisa Town, Jishi County, Jiangxi Province }\end{array}$ & $115.47^{\circ} \mathrm{E}$ & $26.98^{\circ} \mathrm{N}$ & $\begin{array}{l}\text { 实地调查 } \\
\text { Field survey }\end{array}$ \\
\hline 35 & $\begin{array}{l}\text { 江西省九江市庐山区白鹿洞 } \\
\text { Bailudong, Lushan District, Jiujiang City, Jiangxi Province }\end{array}$ & $116.05^{\circ} \mathrm{E}$ & $29.52^{\circ} \mathrm{N}$ & CVH LBG 00018208 \\
\hline
\end{tabular}


附录I (续) Appendix I (continued)

\begin{tabular}{|c|c|c|c|c|}
\hline 序号 & 居群位置 & 经度 & 纬度 & 来源 \\
\hline Code & Location of populations & Longitude & Latitude & Source \\
\hline \multirow[t]{2}{*}{$\overline{36}$} & 江西省九江县岷山乡 & $115.66^{\circ} \mathrm{E}$ & $29.46^{\circ} \mathrm{N}$ & CVH HHBG HZ003664 \\
\hline & Minshan Township, Jiujiang County, Jiangxi Province & & & \\
\hline \multirow[t]{2}{*}{37} & 江西省彭泽县钱家湾 & $116.75^{\circ} \mathrm{E}$ & $30.05^{\circ} \mathrm{N}$ & CVH NAS 00203760 \\
\hline & Qianjiawan, Pengze County, Jiangxi Province & & & \\
\hline \multirow[t]{2}{*}{38} & 江西省武宁县鲁溪镇 & $115.20^{\circ} \mathrm{E}$ & $29.50^{\circ} \mathrm{N}$ & 实地调查 \\
\hline & Luxi Town, Wuning County, Jiangxi Province & & & Field survey \\
\hline \multirow[t]{2}{*}{39} & 江西省武宁县甫田乡 & $114.88^{\circ} \mathrm{E}$ & $29.30^{\circ} \mathrm{N}$ & 实地调查 \\
\hline & Futian Township, Wuning County, Jiangxi Province & & & Field survey \\
\hline \multirow[t]{2}{*}{40} & 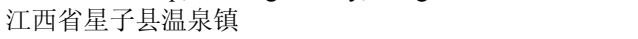 & $115.90^{\circ} \mathrm{E}$ & $29.42^{\circ} \mathrm{N}$ & CVH KUN 504149 \\
\hline & Wenquan Town, Xingzi County, Jiangxi Province & & & \\
\hline \multirow[t]{2}{*}{41} & 江西省修水县 & $114.54^{\circ} \mathrm{E}$ & $29.03^{\circ} \mathrm{N}$ & CVH NAS 00203795 \\
\hline & Xiushui County, Jiangxi Province & & & \\
\hline \multirow[t]{2}{*}{42} & 江西省永修县 & $115.62^{\circ} \mathrm{E}$ & $29.09^{\circ} \mathrm{N}$ & 实地调查 \\
\hline & Yongxiu County, Jiangxi Province & & & Field survey \\
\hline \multirow[t]{2}{*}{43} & 江西省德兴市大茅山 & $117.75^{\circ} \mathrm{E}$ & $28.92^{\circ} \mathrm{N}$ & CVH LBG 00018216 \\
\hline & Damao Mountain, Dexing City, Jiangxi Province & & & \\
\hline \multirow[t]{2}{*}{44} & 江西省鄱阳县侯岗村 。 & $116.86^{\circ} \mathrm{E}$ & $29.53^{\circ} \mathrm{N}$ & CVH LBG 00018224 \\
\hline & Hougang Village, Poyang County, Jiangxi Province & & & \\
\hline \multirow[t]{2}{*}{45} & 江西省鄱阳县千秋河 & $116.88^{\circ} \mathrm{E}$ & $29.36^{\circ} \mathrm{N}$ & CVH NAS 00203763 \\
\hline & Qianqiuhe, Poyang County, Jiangxi Province & & & \\
\hline \multirow[t]{2}{*}{46} & 江西省宜丰县官山自然保护区 & $114.57^{\circ} \mathrm{E}$ & $28.50^{\circ} \mathrm{N}$ & CVH LBG 00018217 \\
\hline & Guanshan Nature Reserve, Yifeng County, Jiangxi Province & & & \\
\hline \multirow[t]{2}{*}{47} & 江西省嵍源县鹤溪村 & $117.87^{\circ} \mathrm{E}$ & $29.23^{\circ} \mathrm{N}$ & 实地调查 \\
\hline & Hexi Village, Wuyuan County, Jiangxi Province & & & Field survey \\
\hline \multirow[t]{2}{*}{48} & 江西省玉山县陇首村 & $117.91^{\circ} \mathrm{E}$ & $28.90^{\circ} \mathrm{N}$ & CVH LBG 00018218 \\
\hline & Longshou Village, Yushan County, Jiangxi Province & & & \\
\hline \multirow[t]{2}{*}{49} & 江西省铜鼓县大沩山 & $114.28^{\circ} \mathrm{E}$ & $28.49^{\circ} \mathrm{N}$ & CVH LBG 00018203 \\
\hline & Dawei Mountain, Tonggu County, Jiangxi Province & & & \\
\hline \multirow[t]{2}{*}{50} & 浙江省临安市太庙山 & $119.73^{\circ} \mathrm{E}$ & $30.24^{\circ} \mathrm{N}$ & SRSPE $2151 \mathrm{C} 0001 \mathrm{~T} 00066148$ \\
\hline & Taimiao Mountain, Lin'an City, Zhejiang Province & & & \\
\hline \multirow[t]{2}{*}{51} & 浙江省临安市指南村 & $119.57^{\circ} \mathrm{E}$ & $30.36^{\circ} \mathrm{N}$ & 实地调查 \\
\hline & Zhinan Village, Lin'an City, Zhejiang Province & & & Field survey \\
\hline \multirow[t]{2}{*}{52} & 浙江省松阳县香奶山 & $119.28^{\circ} \mathrm{E}$ & $28.40^{\circ} \mathrm{N}$ & SRSPE $2151 \mathrm{C} 0001 \mathrm{~S} 60002828$ \\
\hline & Xiangnai Mountain, Songyang County, Zhejiang Province & & & \\
\hline \multirow[t]{2}{*}{53} & 浙江省余姚市四明山 & $121.12^{\circ} \mathrm{E}$ & $29.74^{\circ} \mathrm{N}$ & CVH PE 00296654 \\
\hline & Siming Mountain, Yuyao City, Zhejiang Province & & & \\
\hline \multirow[t]{2}{*}{54} & 浙江省诸暨市七家龙 & $120.37^{\circ} \mathrm{E}$ & $29.81^{\circ} \mathrm{N}$ & CVH NAS 00203798 \\
\hline & Qijialong, Zhuji City, Zhejiang Province & & & \\
\hline \multirow[t]{2}{*}{55} & 浙江省诸暨市外陈村 & $120.19^{\circ} \mathrm{E}$ & $29.66^{\circ} \mathrm{N}$ & CVH PE 00296650 \\
\hline & Waichen Village, Zhuji City, Zhejiang Province & & & \\
\hline
\end{tabular}

CVH, 中国数字植物标本馆, 其后代码为标本的馆藏条码; PPBC, 中国植物图像库, 其后代码为图片编号; SRSPE, 教学标本资源共享平台, 其后代码 为标本的平台资源号。

CVH, Chinese Virtual Herbarium, subsequent code represents the specimen bar code in the herbarium; PPBC, Plant Photo Bank of China, subsequent code represents the photo ID; SRSPE, Specimen Resources Sharing Platform for Education, subsequent code represents the resource number in the platform.

\section{参考文献}

Fang TQ (2012). Preliminary report on the regional botanical resources survey of Jingangtai National Geopark in Jinzhai County. Anhui Forestry Science and Technology, 38(4), 19-21. (in Chinese with English abstract) [方泰泉 (2012). 金刚台国家地质公园(金寨)区域植物资源调查初报. 安徽林业科技, 38(4), 19-21.]

Lü Y, Zhang J, Zang H (2013). Analysis of Castanopsis sclerophylla mixed stand's natural compose index. Scientia Silvae Sinicae, 49(7), 86-90. (in Chinese with English abstract) [吕勇, 张江, 㶓影 (2013). 苦槠混交林自然构成指数分析. 林业科学, 49(7), 86-90.]

Ye YZ, Li PX, Qu WY (2014). Science Survey of Henan Jigongshan Nature Reserve. Science Press, Beijing. (in Chinese) [叶永忠, 李培学, 㫿文元 (2014). 河南鸡公山国家级自然保护区科学考察集. 科学出版社, 北京.] 
附录II 八个环境变量的边缘响应曲线

Appendix II Marginal response curves for eight environmental variables
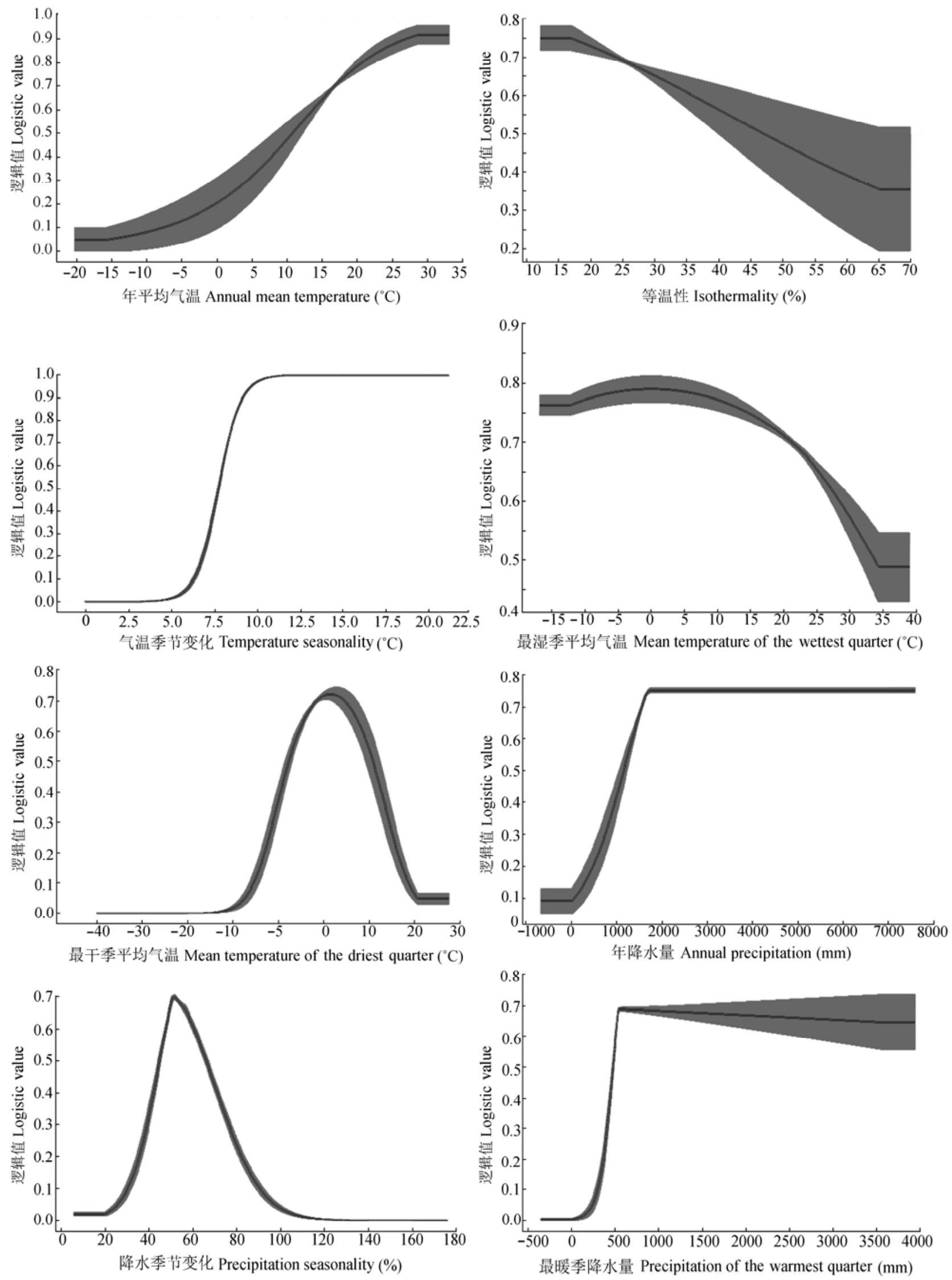
附录III 八个环境变量的单变量响应曲线

Appendix III Single variable response curves for eight environmental variables
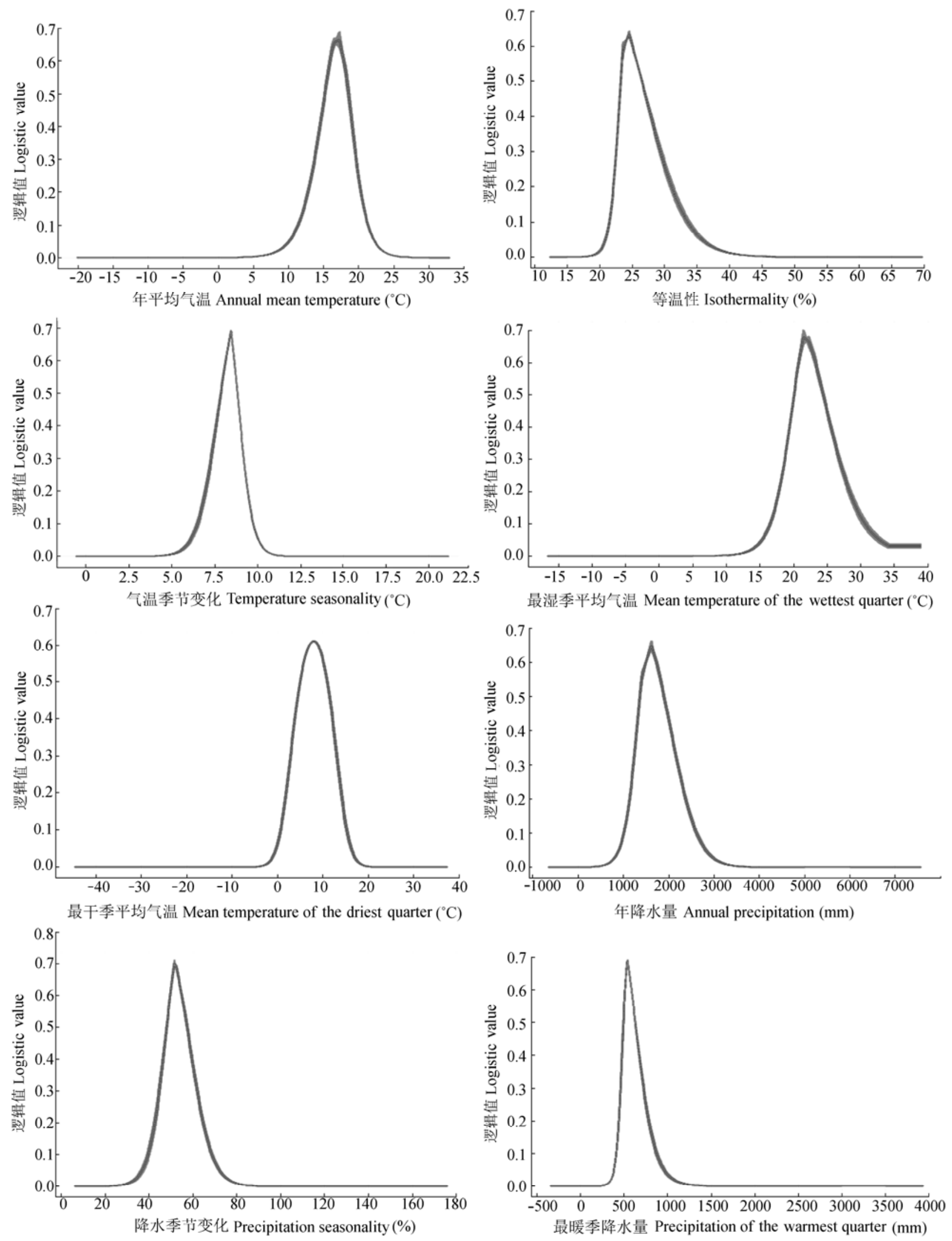